\title{
Effect of Repeated Freeze-Thaw Cycles on Beef Quality and Safety
}

\author{
Mohammad Hafizur Rahman¹, Mohammad Mujaffar Hossain1, Syed Mohammad Ehsanur Rahman ${ }^{1, \#,}$ \\ Mohammad Abul Hashem ${ }^{1}$, and Deog-Hwan Oh* \\ Department of Food Science and Biotechnology, Kangwon National University, Chuncheon 200-701, Korea \\ ${ }^{1}$ Department of Animal Science, Bangladesh Agricultural University, Mymensingh 2202, Bangladesh
}

\begin{abstract}
The objectives of this study were to know the effect of repeated freeze-thaw cycles of beef on the sensory, physicochemical quality and microbiological assessment. The effects of three successive freeze-thaw cycles on beef forelimb were investigated comparing with unfrozen fresh beef for $75 \mathrm{~d}$ by keeping at $-20 \pm 1^{\circ} \mathrm{C}$. The freeze-thaw cycles were subjected to three thawing methods and carried out to know the best one. As the number of freeze-thaw cycles increased color and odor declined significantly before cook within the cycles and tenderness, overall acceptability also declined among the cycles after cook by thawing methods. The thawing loss increased and dripping loss decreased significantly $(p<0.05)$. Water holding capacity (WHC) increased $(p<0.05)$ until two cycles and then decreased. Cooking loss increased in cycle 1 and 3, but decreased in cycle 2 . $\mathrm{pH}$ decreased significantly $(p<0.05)$ among the cycles. Moreover, drip loss, cooking loss and WHC were affected $(p<0.05)$ by thawing methods within the cycles. 2-Thiobarbituric acid (TBARS) value increased $(p<0.05)$ gradually within the cycles and among the cycles by thawing methods. Total viable bacteria, total coliform and total yeast-mould count decreased significantly $(p<0.05)$ within and among the cycles in comparison to the initial count in repeated freeze-thaw cycles. As a result, repeated freeze-thaw cycles affected the sensory, physicochemical and microbiological qua- lity of beef, causing the deterioration of beef quality, but improved the microbiological quality. Although repeated freeze-thaw cycles did not affect much on beef quality and safety but it may be concluded that repeated freeze and thaw should be minimized in terms of beef color for commercial value and WHC and tenderness/juiciness for eating quality.
\end{abstract}

Keywords: repeated, freeze-thaw, cycle, beef, quality, safety, sensory

\section{Introduction}

Nowadays different preservation methods of meat have been developed among which freezing is most useful over the world (Sultana et al., 2008). Freezing has been an excellent preserving technique for meat and its products for long time in which meat and meat products can be preserved in a condition similar to that of normal state and can be kept satisfactory for six months or one year but with poor procedures the quality of meat deteriorates within a few days. Fresh meat remains almost same food value and flavor after proper freezing. Freezing and thawing are complex processes that involve heat transfer as well as a series of physical and chemical changes which can affect the quality of the meat products (Bing et al., 2002). The

\footnotetext{
${ }^{\#}$ This author contributed as a corresponding author.

*Corresponding author: Deog-Hwan Oh, Department of Food Science and Biotechnology, Kangwon National University, Chuncheon 200-701, Korea. Tel: +82-33-250-6457, Fax: +8233-250-6457, E-mail: deoghwa@kangwon.ac.kr
}

quality of meat is generally determined by appearance, texture, flavor, color, microbial activity and nutritive value. Meat quality is influenced by the rate at which freezing and thawing are performed (McMillin, 2008). In recent years, food industry has relied more and more on using thawed meat in meat processing. Freezing commercially at $-18^{\circ} \mathrm{C}$ and domestically at $-10^{\circ} \mathrm{C}$ is now a standard of eating quality compared to fresh meat and $-18^{\circ} \mathrm{C}$ to $-20^{\circ} \mathrm{C}$ freezing temperature is effective for both preservation of meat and further manufacturing of meat (Farouk et al., 2004; Soyer et al., 2010). Thawing commercially and domestically at refrigerator temperature $\left(4^{\circ} \mathrm{C}\right)$ (Estridge and Bowker, 2011), temperatures ranging from room temperature to $49^{\circ} \mathrm{C}$ or microwave (Chemat et al., 2011), and running tap water (USDA's FSIS) were practiced for meat thawing. Repeated freezing procedures influence thawing loss, color and tenderness of meat (Farouk and Swan, 1998; Honikel et al., 1986). When the number of freeze-thaw cycles increased, the thawing losses, cooking loss increased. Jin-ping et al. (2012) reported that repeated freeze-thaw improved meat tenderness. Jun et al. (2012) 
studied that lipid oxidation increased with repeated freezethaw cycles. Repeated freeze-thaw cycles affected the physicochemical quality and protein degradation of beef muscle, causing the degradation of beef quality (Jin-ping et al., 2012). The effect of repeated freeze-thaw cycles on beef especially sensory, physicochemical quality and microbiological safety has not been fully elucidated. For these reasons the present study was undertaken.

\section{Materials and Methods}

\section{Experimental samples}

The samples were obtained from forelimb of a bull which is around 2 year-old and weighing live weight of $250 \pm 5 \mathrm{~kg}$. After removing the fat, ligaments, bone and tendons from the muscles, they were randomly divided into twenty seven samples. The sensory properties like color, smell, juiciness, tenderness and overall acceptability were observed. The physicochemical properties like moisture loss, $\mathrm{pH}$, and lipid oxidation as TBARS value were analyzed. The microbial assessment through total viable count (TVC), coliform count, and yeast-mould count in the laboratory. The fresh beef was used as control i.e. not frozen or thawed.

\section{Freezing and thawing}

The samples were frozen in a blast freezer set at $-20^{\circ} \mathrm{C}$ with a wind speed of $2.6 \mathrm{~m} / \mathrm{s}$. The temperature of the freeze was checked regularly. The samples were stored for $80 \mathrm{~d}$. The samples were stored for $40 \pm 2 \mathrm{~d}$ for first cycle; $20 \pm 2 \mathrm{~d}$ for second cycle; $15 \pm 2 \mathrm{~d}$ for third cycle at $-20 \pm 1^{\circ} \mathrm{C}$ before thawing. The three methods of thawing were achieved using two thawing mediums and various temperatures. Thawing methods were carried out at $4 \pm$ $1^{\circ} \mathrm{C}$ in a refrigeration unit; under tap water $\left(27 \pm 1^{\circ} \mathrm{C}\right)$ and warm water $\left(40 \pm 1^{\circ} \mathrm{C}\right)$ and thaw for minimum time.

\section{Sensory evaluation}

Raw and cooked beef samples were analyzed for their freshness, texture, odor, spoilage/decay and overall acceptability by 10 trained and untrained panelists familiar with beef evaluation after thawing in three methods. Panelists were selected among department staff and students and trained according to the American Meat Science Association guidelines (AMSA, 1995). Sensory evaluation was carried out in individual booths under controlled conditions of light, temperature and humidity. Prior to sample evaluation, all panelists participated in orientation sessions to familiarize with the scale attributes (off-odor, freshness, overall and so on) of raw beef using an intensity scale. Sensory qualities of the samples were evaluated after thawing of before cook and after cook using a 5 -point scoring method. Sensory scores were 5 for excellent, 4 for very good, 3 for good, 2 for fair and 1 for poor (Rahman et al., 2012). In particular, for spoilage of samples, panelists observed the degree of spoilage by appearance (discoloration and slime formation). All samples were served in the petri-dishes. Sensory evaluation was accomplished at $40 \mathrm{~d}$ and repeated at $60 \mathrm{~d}$ and $75 \mathrm{~d}$; up to the end of refrigerated storage at $-20 \pm 1^{\circ} \mathrm{C}$.

\section{Physicochemical properties of beef}

\section{Thaw loss}

Thaw loss was determined by weighing each whole muscle prior to freezing and again after thawing and blotting dry with tissue paper. Thaw loss was expressed as a percentage of initial weight prior to freezing.

Thaw loss $(\%)=$

[(sample weight before freezing $(\mathrm{g})$ - sample weight after thawing $(\mathrm{g}))$ / sample weight before freezing $(\mathrm{g})] \times$ 100

\section{Drip loss}

Meat samples were cut from the carcass and immediately weighed. A sample weight of approximately 80$100 \mathrm{~g}$ was recommended but other sample sizes may also be used. Drip loss was determined by suspending individually weighed steaks in inflated polythene bags (taking care that samples did not touch the sides of the bags) for $24 \mathrm{~h}$ at $4^{\circ} \mathrm{C}$. After $24 \mathrm{~h}$, samples were removed, gently blotted dry and weighed; drip loss was calculated as the percentage of weight lost.

Drip loss $(\%)=$

[(sample weight $(\mathrm{g})-24 \mathrm{hrs}$ after sample weight $(\mathrm{g}))$ / sample weight $(\mathrm{g})] \times 100$

\section{Cooking loss}

To determine cooking loss, weighed $5 \pm 1 \mathrm{~g}$ samples and wrapped in a heat-stable foil paper and kept in water bath at $80^{\circ} \mathrm{C}$ for $30 \mathrm{~min}$. The internal temperature was not measured, but from a previous study (Sultana et al., 2008). It was estimated that the optimum internal meat temperature $\left(75-80^{\circ} \mathrm{C}\right)$ would be gained by $30 \mathrm{~min}$. Samples surface was dried and weighed. Cook loss was calculated after draining the drip coming from the cooked meat as follows: 
Cook loss $(\%)=\left[\left(\mathrm{w}_{2}-\mathrm{w}_{3}\right) / \mathrm{w}_{2}\right] \times 100$

where, $\mathrm{w}_{2}=$ meat weight before cooking $(\mathrm{g})$ and $\mathrm{w}_{3}=$ meat weight after cooking (g).

\section{Water holding capacity}

Muscle water-holding capacity (WHC) was determined by the filter paper press method (Grau and Hamm, 1953). Each piece of meat $\left(1 \times 1 \times 1.5 \mathrm{~cm}^{3}\right)$ was covered with eight sheets of filter paper and pressed with a $12 \mathrm{~kg}$ load for two minutes. The water holding capacity was calculated as follows:

\section{WHC $(\%)=$}

$[1-\{$ (meat weight before pressing $(\mathrm{g})-$ meat weight after pressing $(\mathrm{g})) /$ (meat weight before pressing $(\mathrm{g}) \times$ moisture content in gram) $\}] \times 100$

\section{Measurement of $\mathrm{pH}$}

Samples $(5 \mathrm{~g})$ were homogenized in $45 \mathrm{~mL}$ of distilled water using a grinder (SFM1500NM, Shinil Co. China) for $1 \mathrm{~min}$. Sample solutions were centrifuged for $15 \mathrm{~min}$ at 2,000 $\mathrm{g}$, and the $\mathrm{pH}$ was measured using a $\mathrm{pH}$ meter (Seven Easy pH, Mettler-Toledo GmbH, Switzerland). The $\mathrm{pH}$ of frozen beef was measured just after thawing.

\section{Measurement of lipid oxidation}

The lipid oxidation value of beef was determined by the methods of Buege and Aust (1978) and Ahn et al. (1998). Samples $(5 \mathrm{~g})$ were homogenized in $15 \mathrm{~mL}$ of distilled water using a blender for $1 \mathrm{~min}$. Sample solutions $(1 \mathrm{~mL})$ were then transferred into a disposable test tube and $2 \mathrm{~mL}$ of $20 \mathrm{mM}$ 2-thiobarbituric acid/15\% trichloroacetic acid (TBA/TCA) solution was added. The mixture was vortexed and boiled in a water bath for $15 \mathrm{~min}$ and cooled at room temperature for $10 \mathrm{~min}$. After centrifugation for 15 min at 2,000 $\mathrm{g}$, the absorbance of resulting supernatant solution was determined at $531 \mathrm{~nm}$ wavelength. TBARS values were calculated from a standard curve and expressed as mg malonaldehyde/kg sample (MA/kg).

\section{Microbiological analysis}

Beef sample ( $25 \mathrm{~g})$ was aseptically homogenized with $225 \mathrm{~mL}$ of sterile peptone water (EMD Buffered peptone water granulated, EMD Chemicals Inc., USA) $(1 \mathrm{~g} / \mathrm{L})$ in a stomacher bag with stomacher blender (Stomacher ${ }^{\circledR} 400$ Circulator, Seward Ltd., U.K.) for 5 min. Serial dilutions were prepared. Total plate counts (TPC) was measured by pouring $0.1 \mathrm{~mL}$ of each dilution on duplicate plates, and then were poured by plate count agar (EMD dehydrated plate count agar granulated, EMD Chemicals Inc.). After $48 \mathrm{~h}$ incubation at $37^{\circ} \mathrm{C}$, colonies were counted according to ISO (1995) and results were expressed as Log CFU/g beef sample. Total coliform was measured by spreading $0.1 \mathrm{~mL}$ of each dilution with a bent sterile polypropylene rod on duplicate plates of prepoured and dried MacConkey agar (EMD dehydrated MacConkey agar granulated, EMD Chemicals Inc.). After $48 \mathrm{~h}$ incubation at $37^{\circ} \mathrm{C}$, colonies were counted according to ISO (1995) and results were expressed as Log CFU/g sample. Total yeast and mould was measured by spreading $0.1 \mathrm{~mL}$ of each dilution with a bent sterile polypropylene rod on duplicate plates of prepoured and dried standard potato dextrose agar (EMD Dehydrated potato dextrose agar granulated). After $72 \mathrm{~h}$ incubation at $25^{\circ} \mathrm{C}$, colonies were counted according to ISO (1995) and results were expressed as Log $\mathrm{CFU} / \mathrm{g}$ sample.

\section{Experimental design and statistical analysis}

The three treatments $\left(\mathrm{T}_{1}=4^{\circ} \mathrm{C}, \mathrm{T}_{2}=40^{\circ} \mathrm{C}\right.$ and $\mathrm{T}_{3}=$ tap water) resulted from three repeated freeze-thaw cycles. Different tests were repeated thrice time on every cycle. Data were statistically analyzed using Completely Randomized Design (CRD) model procedure by JMP (SAS Statistical Discovery software, USA). The $3 \times 3$ factorial design was used for cycle-treatment interaction analysis. Tukey HSD test was used to determine the significance of differences among treatments means.

\section{Results}

\section{Sensory evaluation}

\section{Color}

The color of the samples was observed after thawing before cook and after cook in each freeze-thaw cycles (1$3)$. The color was almost similar to control but slightly varied by thawing methods within and among the cycles before cook (Fig. 1-3). In cycle 1 and 2, thawing at $4^{\circ} \mathrm{C}$ the color was very good but thawing at $40^{\circ} \mathrm{C}$ and in tap water, color was good and changed significantly $(p<$ $0.01)$. In cycle 3 , thawing in tap water the color was better than $4^{\circ} \mathrm{C}$ and $40^{\circ} \mathrm{C}$ thawing. In this experiment, interactive effects were observed $(p<0.01)$ on color in different cycles and thawing methods. Thawing at $4^{\circ} \mathrm{C}$ in cycle 1 showed the highest score of color, but while thawing at $40^{\circ} \mathrm{C}$ in cycle 2 showed the lowest score of color than other interactions (Table 5). 


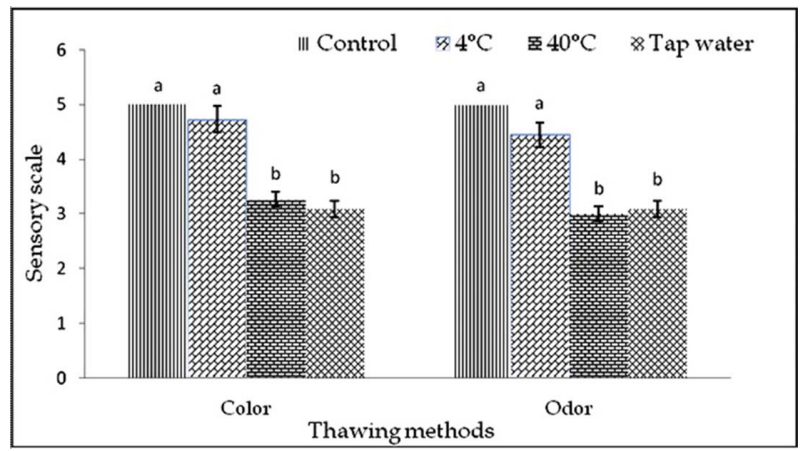

Fig. 1. Changes of color and odor $(\operatorname{mean} \pm \mathrm{SE})$ in thawed beef samples before cook compared to control in freezethaw cycle -1 .

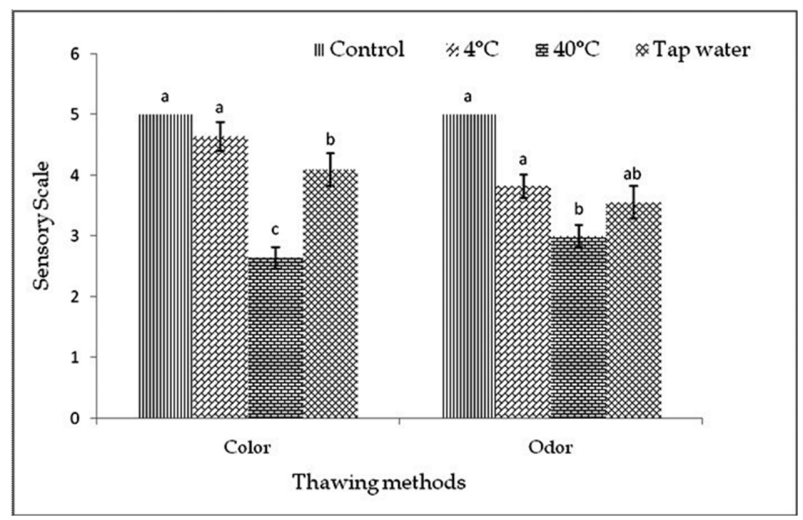

Fig. 2. Changes of color and odor (mean \pm SE) in thawed beef samples before cook compared to control in freezethaw cycle -2 .

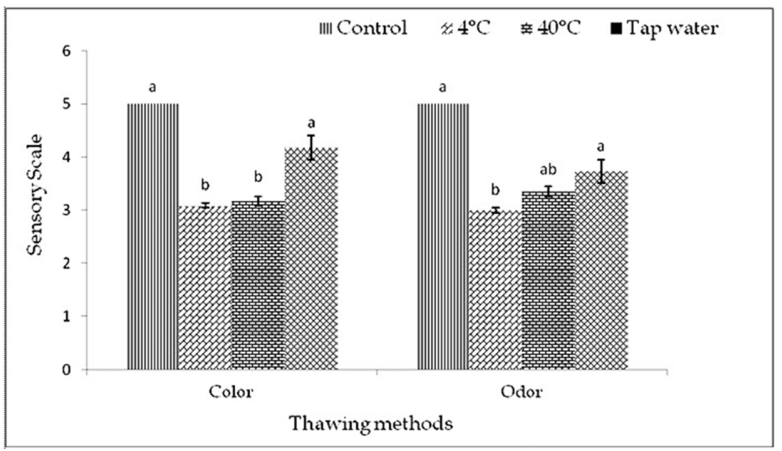

Fig. 3. Changes of color and odor (mean \pm SE) in thawed beef samples before cook compared to control in freezethaw cycle -3 .

Thawing methods did not affect $(p>0.05)$ the color after cook within different cycles or among the cycles (Table 1, 3 and 4 ) except cycle $2(p<0.05)$ (Table 2$)$. There were no significant $(p>0.05)$ interactive effects on color in different cycles and thawing methods. Thawing in tap water in cycle 2 had better score of color in cycles-thawing interaction methods (Table 6).

\section{Odor}

The odor was almost similar to control but differed by different thawing methods within and among the cycles before cook (Fig. 1-3). In cycle 1, thawing at $4^{\circ} \mathrm{C}$ the odor was very good but thawing at $40^{\circ} \mathrm{C}$ and in tap water, odor was good and changed significantly $(p<0.01)$. In cycle 2 and 3 , thawing at $4{ }^{\circ} \mathrm{C}, 40^{\circ} \mathrm{C}$ and in tap water the odor

Table 1. Changes of sensory attributes (mean $\pm \mathrm{SE}$ ) in thawed beef samples after cook compared to control in freeze-thaw cycle $\mathbf{- 1}$

\begin{tabular}{cccccc}
\hline \hline \multirow{2}{*}{ Thawing Methods } & \multicolumn{5}{c}{ Sensory Attributes } \\
\cline { 2 - 6 } & Color & Odor & Tenderness & Juiciness & Overall Acceptability \\
\hline Control & $5.00 \pm 0.00$ & $5.00 \pm 0.00$ & $5.00 \pm 0.00$ & $5.00 \pm 0.00$ & $5.00^{\mathrm{a}} \pm 0.00$ \\
$4^{\circ} \mathrm{C}$ & $3.73 \pm 0.24$ & $3.73 \pm 0.25$ & $4.00 \pm 0.26$ & $4.09 \pm 0.28$ & $4.64^{\mathrm{a}} \pm 0.19$ \\
$40^{\circ} \mathrm{C}$ & $3.73 \pm 0.24$ & $3.91 \pm 0.25$ & $4.00 \pm 0.26$ & $3.73 \pm 0.28$ & $3.64^{\mathrm{b}} \pm 0.19$ \\
Tap water & $3.55 \pm 0.24$ & $3.73 \pm 0.25$ & $3.82 \pm 0.26$ & $3.64 \pm 0.28$ & $4.00^{\mathrm{b}} \pm 0.19$ \\
Level of significance & NS & NS & NS & NS & $* *$ \\
\hline
\end{tabular}

Means with different superscripts in each column are significantly different $(* * p<0.01)$. NS was not significantly different. Sensory scores were based on 5 point descriptive scale, where $5=$ Excellent, $4=$ Very good, $3=$ Good, $2=$ Fair, $1=$ Poor.

Table 2. Changes of sensory attributes $(\operatorname{mean} \pm \mathrm{SE})$ in thawed beef samples after cook compared to control in freeze-thaw cycle $\mathbf{- 2}$

\begin{tabular}{cccccc}
\hline \hline \multirow{2}{*}{ Thawing Methods } & \multicolumn{5}{c}{ Sensory Attributes } \\
\cline { 2 - 6 } & Color & Odor & Tenderness & Juiciness & Overall Acceptability \\
\hline Control & $5.00^{\mathrm{a}} \pm 0.00$ & $5.00 \pm 0.00$ & $5.00^{\mathrm{a}} \pm 0.00$ & $5.00^{\mathrm{a}} \pm 0.00$ & $5.00 \pm 0.00$ \\
$4^{\circ} \mathrm{C}$ & $3.73^{\mathrm{b}} \pm 0.21$ & $3.91 \pm 0.21$ & $4.00^{\mathrm{ab}} \pm 0.27$ & $3.91^{\mathrm{ab}} \pm 0.26$ & $4.00 \pm 0.23$ \\
$40^{\circ} \mathrm{C}$ & $3.82^{\mathrm{b}} \pm 0.21$ & $3.82 \pm 0.21$ & $3.55^{\mathrm{b}} \pm 0.27$ & $3.27^{\mathrm{b}} \pm 0.26$ & $3.55 \pm 0.23$ \\
Tap water & $4.45^{\mathrm{a}} \pm 0.21$ & $4.18 \pm 0.21$ & $4.55^{\mathrm{a}} \pm 0.27$ & $4.45^{\mathrm{a}} \pm 0.26$ & $4.36 \pm 0.23$ \\
Level of significance & $*$ & NS & $*$ & $*$ & NS \\
\hline
\end{tabular}

Means with different superscripts in each column are significantly different $\left({ }^{*} p<0.05\right)$. NS was not significantly different. Sensory scores were based on 5 point descriptive scale, where $5=$ Excellent, $4=$ Very good, $3=$ Good, $2=$ Fair, $1=$ Poor. 
Table 3. Changes of sensory attributes (mean $\pm \mathrm{SE})$ in thawed beef samples after cook compared to control in freeze-thaw cycle -3

\begin{tabular}{cccccc}
\hline \hline \multirow{2}{*}{ Thawing Methods } & \multicolumn{5}{c}{ Sensory Attributes } \\
\cline { 2 - 6 } & Color & Odor & Tenderness & Juiciness & Overall Acceptability \\
\hline Control & $5.00 \pm 0.00$ & $5.00 \pm 0.00$ & $5.00 \pm 0.00$ & $5.00 \pm 0.00$ & $5.00 \pm 0.00$ \\
$4^{\circ} \mathrm{C}$ & $3.73 \pm 0.22$ & $3.55 \pm 0.19$ & $3.18 \pm 0.25$ & $3.45 \pm 0.23$ & $3.55 \pm 0.22$ \\
$40^{\circ} \mathrm{C}$ & $3.55 \pm 0.22$ & $3.55 \pm 0.19$ & $3.27 \pm 0.25$ & $3.36 \pm 0.23$ & $3.36 \pm 0.22$ \\
Tap water & $3.91 \pm 0.22$ & $3.91 \pm 0.19$ & $3.45 \pm 0.25$ & $3.45 \pm 0.23$ & $3.73 \pm 0.22$ \\
Level of significance & NS & NS & NS & NS & NS \\
\hline
\end{tabular}

NS was not significantly different. Sensory scores were based on 5 point descriptive scale, where $5=$ Excellent, $4=$ Very good, $3=$ Good, $2=$ Fair, $1=$ Poor

Table 4. Changes of sensory attributes $($ mean $\pm \mathrm{SE})$ in thawed beef samples after cook compared to control in repeated cycles

\begin{tabular}{cccccc}
\hline \hline \multirow{2}{*}{ Cycles } & \multicolumn{5}{c}{ Sensory Attributes } \\
\cline { 2 - 6 } & Color & Odor & Tenderness & Juiciness & Overall Acceptability \\
\hline Control & $5.00 \pm 0.00$ & $5.00 \pm 0.00$ & $5.00^{\mathrm{a}} \pm 0.00$ & $5.00 \pm 0.00$ & $5.00^{\mathrm{a}} \pm 0.00$ \\
Cycle 1 & $3.67 \pm 0.22$ & $3.79 \pm 0.13$ & $3.94^{\mathrm{a}} \pm 0.15$ & $3.82 \pm 0.15$ & $4.09^{\mathrm{a}} \pm 0.21$ \\
Cycle 2 & $4.00 \pm 0.22$ & $3.97 \pm 0.13$ & $4.03^{\mathrm{a}} \pm 0.15$ & $3.88 \pm 0.15$ & $3.97^{\mathrm{a}} \pm 0.21$ \\
Cycle 3 & $3.73 \pm 0.22$ & $3.67 \pm 0.13$ & $3.30^{\mathrm{b}} \pm 0.15$ & $3.42 \pm 0.15$ & $3.55^{\mathrm{b}} \pm 0.21$ \\
Level of significance & NS & NS & $*$ & NS & $*$ \\
\hline
\end{tabular}

Means with different superscripts in each column are significantly different $\left({ }^{*} p<0.05\right)$. NS was not significantly different. Sensory scores were based on 5 point descriptive scale, where $5=$ Excellent, $4=$ Very good, $3=$ Good, $2=$ Fair, $1=$ Poor.

Table 5. Freezing-thawing interactive effects on sensory quality (mean \pm SE) of thawed beef samples before cook in different cycles and thawing methods

\begin{tabular}{ccc}
\hline \hline Interactions & Color & Odor \\
\hline $\mathrm{C}_{1} \times \mathrm{T}_{1}$ & $4.73^{\mathrm{a}} \pm 0.19$ & $4.46^{\mathrm{a}} \pm 0.22$ \\
$\mathrm{C}_{1} \times \mathrm{T}_{2}$ & $3.27^{\mathrm{bc}} \pm 0.19$ & $3.09^{\mathrm{b}} \pm 0.22$ \\
$\mathrm{C}_{1} \times \mathrm{T}_{3}$ & $3.00^{\mathrm{c}} \pm 0.19$ & $3.09^{\mathrm{b}} \pm 0.22$ \\
$\mathrm{C}_{2} \times \mathrm{T}_{1}$ & $4.64^{\mathrm{a}} \pm 0.19$ & $3.82^{\mathrm{a}} \pm 0.22$ \\
$\mathrm{C}_{2} \times \mathrm{T}_{2}$ & $2.64^{\mathrm{c}} \pm 0.19$ & $3.00^{\mathrm{b}} \pm 0.22$ \\
$\mathrm{C}_{2} \times \mathrm{T}_{3}$ & $4.09^{\mathrm{ab}} \pm 0.19$ & $3.54^{\mathrm{ab}} \pm 0.22$ \\
$\mathrm{C}_{3} \times \mathrm{T}_{1}$ & $3.09^{\mathrm{c}} \pm 0.19$ & $3.00^{\mathrm{b}} \pm 0.22$ \\
$\mathrm{C}_{3} \times \mathrm{T}_{2}$ & $3.18^{\mathrm{c}} \pm 0.19$ & $3.36^{\mathrm{b}} \pm 0.22$ \\
$\mathrm{C}_{3} \times \mathrm{T}_{3}$ & $4.18^{\mathrm{a}} \pm 0.19$ & $3.73^{\mathrm{ab}} \pm 0.22$ \\
Level of Significance & $* *$ & $* *$ \\
\hline
\end{tabular}

Means with different superscripts in each column are significantly different $(* * p<0.01)$. Sensory scores were based on 5 point descriptive scale, where $5=$ Excellent, $4=$ Very good, $3=$ Good, $2=$ Fair, $1=$ Poor.

Note: $\mathrm{C}=$ Cycle $\left(\mathrm{C}_{1}=\right.$ Cycle $1 ; \mathrm{C}_{2}=$ Cycle $2 ; \mathrm{C}_{3}=$ Cycle 3$)$ and $\mathrm{T}=$ Treatment/thawing methods $\left(\mathrm{T}_{1}=4^{\circ} \mathrm{C}, \mathrm{T}_{2}=40^{\circ} \mathrm{C}, \mathrm{T}_{3}=\right.$ Tap water $)$.

was significantly $(p<0.05)$ changed. The thawing methods did not affect $(p>0.05)$ the odor among different cycles, before cook but significant $(p<0.01)$ interactive effects were found on odor in different cycles and thawing methods. Thawing at $4^{\circ} \mathrm{C}$ in cycle 1 had the highest and thawing at $40^{\circ} \mathrm{C}$ in cycle 2 and thawing at $4^{\circ} \mathrm{C}$ in cycle 3 had the lowest score of odor (Table 5).

Thawing methods did not affect $(p>0.05)$ odor after cook within different cycles or among the cycles (Table 1-4). Moreover, different cycles and thawing methods interactions had no effect $(p>0.05)$ on odor (Table 6).

\section{Tenderness}

Different thawing methods did not affect $(p>0.05)$ tenderness within cycle 1 and 3 (Table 1 and 3 ), but in cycle 2 significant change $(p<0.05)$ was found (Table 2). Among the freeze-thaw cycles, tenderness was significantly $(p<$ 0.05 ) changed (Table 4$)$. There were no significant interactive effects on tenderness in different cycles and thawing methods. As the number of repeated freeze-thaw cycles increased, tenderness of beef samples increased little. Thawing in tap water in cycle 2 had the highest score of tenderness among the interactions (Table 6).

\section{Juiciness}

Different thawing methods did not affect $(p>0.05)$ juiciness within cycle 1 and 3 (Table 1 and 3), but in cycle 2 significant $(p<0.05)$ change was found (Table 2). Again no significant $(p<0.05)$ change on juiciness was found among the freeze-thaw cycles (Table 4). There were no significant $(p>0.05)$ interactive effects on juiciness in different cycles and thawing methods. As the number of repeated freeze-thaw cycles increased juiciness of beef samples was decreased. Thawing in tap water in cycle 2 had the highest score of juiciness (Table 6).

\section{Overall acceptability}

Thawing at $4^{\circ} \mathrm{C}$ had the highest level of acceptability in freeze-thaw cycle 1 (Table 1) and thawing in tap water had the highest score of acceptability in freeze-thaw cycle 2 and 3 (Table 2 and 3). Thawing methods affected ( $p<$ 
Table 6. Freezing-thawing interactive effects on sensory quality (mean \pm SE) of thawed beef samples after cook in different cycles and thawing methods

\begin{tabular}{|c|c|c|c|c|c|}
\hline Interactions & Color & Odor & Tenderness & Juiciness & Overall Acceptability \\
\hline $\mathrm{C}_{1} \times \mathrm{T}_{1}$ & $3.73 \pm 0.22$ & $3.73 \pm 0.22$ & $4.00 \pm 0.26$ & $4.09 \pm 0.26$ & $4.64 \pm 0.22$ \\
\hline $\mathrm{C}_{1} \times \mathrm{T}_{2}$ & $3.73 \pm 0.22$ & $3.91 \pm 0.22$ & $4.00 \pm 0.26$ & $3.73 \pm 0.26$ & $3.64 \pm 0.22$ \\
\hline $\mathrm{C}_{1} \times \mathrm{T}_{3}$ & $3.54 \pm 0.22$ & $3.73 \pm 0.22$ & $3.82 \pm 0.26$ & $3.64 \pm 0.26$ & $4.00 \pm 0.22$ \\
\hline $\mathrm{C}_{2} \times \mathrm{T}_{1}$ & $3.73 \pm 0.22$ & $3.91 \pm 0.22$ & $4.00 \pm 0.26$ & $3.91 \pm 0.26$ & $4.00 \pm 0.22$ \\
\hline $\mathrm{C}_{2} \times \mathrm{T}_{2}$ & $3.82 \pm 0.22$ & $3.82 \pm 0.22$ & $3.54 \pm 0.26$ & $3.27 \pm 0.26$ & $3.54 \pm 0.22$ \\
\hline $\mathrm{C}_{2} \times \mathrm{T}_{3}$ & $4.45 \pm 0.22$ & $4.18 \pm 0.22$ & $4.54 \pm 0.26$ & $4.45 \pm 0.26$ & $4.36 \pm 0.22$ \\
\hline $\mathrm{C}_{3} \times \mathrm{T}_{1}$ & $3.73 \pm 0.22$ & $3.54 \pm 0.22$ & $3.18 \pm 0.26$ & $3.45 \pm 0.26$ & $3.54 \pm 0.22$ \\
\hline $\mathrm{C}_{3} \times \mathrm{T}_{2}$ & $3.54 \pm 0.22$ & $3.54 \pm 0.22$ & $3.27 \pm 0.26$ & $3.36 \pm 0.26$ & $3.36 \pm 0.22$ \\
\hline $\mathrm{C}_{3} \times \mathrm{T}_{3}$ & $3.91 \pm 0.22$ & $3.91 \pm 0.22$ & $3.45 \pm 0.26$ & $3.45 \pm 0.26$ & $3.73 \pm 0.22$ \\
\hline Level of Significance & NS & NS & NS & NS & NS \\
\hline
\end{tabular}

NS was not significantly different.

Note: $\mathrm{C}=$ Cycle $\left(\mathrm{C}_{1}=\right.$ Cycle $1 ; \mathrm{C}_{2}=$ Cycle $2 ; \mathrm{C}_{3}=$ Cycle 3$)$ and $\mathrm{T}=$ Treatment/Thawing methods $\left(\mathrm{T}_{1}=4^{\circ} \mathrm{C} ; \mathrm{T}_{2}=40^{\circ} \mathrm{C} ; \mathrm{T}_{3}=\right.$ Tap water $)$.

$0.01)$ the overall acceptability in cycle 1 (Table 1) and among the cycles $(p<0.05)$ (Table 4$)$, but no significant $(p>0.05)$ change found on overall acceptability within cycles 2 and 3 (Table 2 and 3) by thawing methods. Moreover, there were no significant interactive effects on overall acceptability in different cycles and thawing methods. Thawing at $4^{\circ} \mathrm{C}$ in cycle 1 had better and thawing at $40^{\circ} \mathrm{C}$ in cycle 3 had the lowest score of overall acceptability among interactions (Table 6).

\section{Physicochemical properties}

\section{Thaw loss}

Fresh unfrozen and unthawed samples had no thaw loss. The thaw loss was increased with the number of freezethaw cycles increased. Different thawing methods had no effect $(p>0.05)$ on thawing loss within cycles (Table 7-9) but had significant effect $(p<0.01)$ among the cycles (Table 10). No interactive effects were found on thaw loss in different freeze-thaw cycles. Thawing at $4^{\circ} \mathrm{C}$ in cycle 1 had the lowest and thawing in tape water in cycle $3 \mathrm{had}$ the highest thawing loss among the interactions (Table 11).

\section{Drip loss}

The initial drip loss of fresh sample was $12.6 \%$. As the number of freeze-thaw cycles increased drip loss was also decreased. Thawing at $4^{\circ} \mathrm{C}$ had the highest and thawing in tap water had the lowest drip loss observed in every cycle. Drip loss was affected $(p<0.01)$ by thawing methods within cycles and among the cycles (Table 7-10). There were significant interactive effects found $(p<0.01)$ on drip loss in different cycles and thawing methods. Thawing at $4^{\circ} \mathrm{C}$ in cycle 1 had the highest and thawing in tap water in cycle 3 had the lowest drip loss among interactions (Table 11).

\section{Cooking loss}

The initial cooking loss of fresh sample was $47.27 \%$. As the number of freeze-thaw cycles increased cooking loss was also increased slightly. The cooking loss was almost similar to control but slightly varied by thawing methods within and among the cycles (Table 7). Thawing at $4^{\circ} \mathrm{C}$ had the highest and thawing at $40^{\circ} \mathrm{C}$ had the lowest cooking loss in every cycle except cycle 3 . Cooking loss was affected $(p<0.01)$ by thawing methods within cycles and among the cycles (Table 7-10). There were significant interactive effects found $(p<0.01)$ on cooking loss in different cycles and thawing methods. Thawing at $4^{\circ} \mathrm{C}$ in cycle 1 had the highest and thawing at $40^{\circ} \mathrm{C}$ in cycle 2 had the lowest cooking loss among the interactions (Table 11).

Table 7. Changes of physicochemical properties $(\operatorname{mean} \pm \mathrm{SE})$ in thawed beef samples compared to control in freeze-thaw cycle -1

\begin{tabular}{cccccc}
\hline \hline \multirow{2}{*}{ Thawing Methods } & \multicolumn{5}{c}{ Physicochemical properties } \\
\cline { 2 - 6 } & Thaw loss \% & Drip loss \% & Cooking loss \% & \% WHC & pH \\
\hline Control & & $12.6^{\mathrm{a}} \pm 0.11$ & $47.27^{\mathrm{ab}} \pm 0.38$ & $69.86^{\mathrm{d}} \pm 0.06$ & $6.15 \pm 0.04$ \\
$4^{\circ} \mathrm{C}$ & $3.49 \pm 0.62$ & $14.05^{\mathrm{a}} \pm 0.14$ & $56.94^{\mathrm{a}} \pm 1.01$ & $77.83^{\mathrm{b}} \pm 0.47$ & $6.04 \pm 0.04$ \\
$40^{\circ} \mathrm{C}$ & $3.66 \pm 0.62$ & $7.04^{\mathrm{b}} \pm 0.14$ & $41.40^{\mathrm{c}} \pm 1.01$ & $79.78^{\mathrm{a}} \pm 0.47$ & $5.92 \pm 0.04$ \\
Tap water & $3.73 \pm 0.62$ & $6.05^{\mathrm{c}} \pm 0.14$ & $45.57^{\mathrm{b}} \pm 1.01$ & $73.81^{\mathrm{c}} \pm 0.47$ & $5.87 \pm 0.04$ \\
Level of significance & NS & $* *$ & $* *$ & $* *$ & NS \\
\hline
\end{tabular}

Means with different superscripts in each column are significantly different $(* * p<0.01)$. NS was not significantly different. 
Table 8. Changes of physicochemical properties (mean $\pm \mathrm{SE}$ ) in thawed beef samples compared to control in freeze-thaw cycle -2

\begin{tabular}{cccccc}
\hline \hline \multirow{2}{*}{ Thawing Methods } & \multicolumn{5}{c}{ Physicochemical properties } \\
\cline { 2 - 6 } & Thaw loss (\%) & Drip loss (\%) & Cooking loss (\%) & WHC (\%) & pH \\
\hline Control & & $12.6^{\mathrm{a}} \pm 0.11$ & $47.27^{\mathrm{a}} \pm 0.38$ & $69.86^{\mathrm{c}} \pm 0.06$ & $6.15^{\mathrm{a}} \pm 0.04$ \\
$4^{\circ} \mathrm{C}$ & $6.13 \pm 0.25$ & $11.42^{\mathrm{a}} \pm 0.23$ & $49.59^{\mathrm{a}} \pm 0.42$ & $74.73^{\mathrm{b}} \pm 0.27$ & $5.72^{\mathrm{a}} \pm 0.04$ \\
$40^{\circ} \mathrm{C}$ & $6.54 \pm 0.25$ & $5.66^{\mathrm{b}} \pm 0.23$ & $41.27^{\mathrm{c}} \pm 0.42$ & $78.58^{\mathrm{a}} \pm 0.27$ & $5.48^{\mathrm{b}} \pm 0.04$ \\
Tap water & $6.57 \pm 0.25$ & $4.90^{\mathrm{b}} \pm 0.23$ & $47.92^{\mathrm{b}} \pm 0.42$ & $73.77^{\mathrm{c}} \pm 0.27$ & $5.39^{\mathrm{b}} \pm 0.04$ \\
Level of significance & NS & $* *$ & $* *$ & $* *$ & $*$ \\
\hline
\end{tabular}

Means with different superscripts in each column are significantly different $\left({ }^{* *} p<0.01\right.$ and $\left.{ }^{*} p<0.05\right)$. NS was not significantly different.

Table 9. Changes of physicochemical properties (mean $\pm \mathrm{SE})$ in thawed beef samples compared to control in freeze-thaw cycle -3

\begin{tabular}{cccccc}
\hline \hline \multirow{2}{*}{ Thawing Methods } & \multicolumn{3}{c}{ Physicochemical properties } \\
\cline { 2 - 6 } & Thaw loss (\%) & Drip loss (\%) & Cooking loss (\%) & WHC (\%) & $\mathrm{pH}$ \\
\hline Control & & $12.6^{\mathrm{a}} \pm 0.11$ & $47.27^{\mathrm{b}} \pm 0.38$ & $69.86^{\mathrm{a}} \pm 0.06$ & $6.15 \pm 0.04$ \\
$4^{\circ} \mathrm{C}$ & $12.51 \pm 0.36$ & $9.92^{\mathrm{a}} \pm 0.13$ & $47.13^{\mathrm{b}} \pm 0.42$ & $54.67^{\mathrm{b}} \pm 0.25$ & $5.48 \pm 0.05$ \\
$40^{\circ} \mathrm{C}$ & $12.76 \pm 0.36$ & $4.57^{\mathrm{b}} \pm 0.13$ & $46.25^{\mathrm{b}} \pm 0.42$ & $56.46^{\mathrm{ab}} \pm 0.25$ & $5.39 \pm 0.05$ \\
Tap water & $12.81 \pm 0.36$ & $4.54^{\mathrm{b}} \pm 0.13$ & $51.16^{\mathrm{a}} \pm 0.42$ & $55.09^{\mathrm{b}} \pm 0.25$ & $5.27 \pm 0.05$ \\
Level of significance & NS & $* *$ & $* *$ & $*$ & NS \\
\hline
\end{tabular}

Means with different superscripts in each column are significantly different $\left({ }^{* *} p<0.01\right.$ and $\left.{ }^{*} p<0.05\right)$. NS was not significantly different.

Table 10. Changes of physicochemical properties (mean $\pm \mathrm{SE}$ ) in thawed beef samples compared to control in repeated cycles

\begin{tabular}{cccccc}
\hline \hline \multirow{2}{*}{ Cycles } & \multicolumn{3}{c}{ Physicochemical properties } \\
\cline { 2 - 6 } & Thaw loss (\%) & Drip loss (\%) & Cooking loss (\%) & WHC (\%) & $\mathrm{pH}$ \\
\hline Control & & $12.6^{\mathrm{a}} \pm 0.11$ & $47.27^{\mathrm{b}} \pm 0.38$ & $69.86^{\mathrm{ab}} \pm 0.06$ & $6.15^{\mathrm{a}} \pm 0.04$ \\
Cycle 1 & $3.625^{\mathrm{c}} \pm 0.15$ & $9.05^{\mathrm{a}} \pm 0.10$ & $47.97^{\mathrm{b}} \pm 0.39$ & $77.14^{\mathrm{a}} \pm 0.20$ & $5.94^{\mathrm{a}} \pm 0.26$ \\
Cycle 2 & $6.416^{\mathrm{b}} \pm 0.15$ & $7.33^{\mathrm{b}} \pm 0.10$ & $46.26^{\mathrm{b}} \pm 0.39$ & $75.69^{\mathrm{b}} \pm 0.20$ & $5.53^{\mathrm{b}} \pm 0.26$ \\
Cycle 3 & $12.69^{\mathrm{a}} \pm 0.15$ & $6.34^{\mathrm{c}} \pm 0.10$ & $48.18^{\mathrm{a}} \pm 0.39$ & $55.45^{\mathrm{c}} \pm 0.20$ & $5.38^{\mathrm{c}} \pm 0.26$ \\
Level of significance & $* *$ & $* *$ & $* *$ & $* *$ & $* *$ \\
\hline
\end{tabular}

Means with different superscripts in each column are significantly different $\left({ }^{* *} p<0.01\right.$ and $\left.{ }^{*} p<0.05\right)$.

\section{Water holding capacity (WHC)}

A significant difference was noted for WHC among beef samples subjected to repeated freeze-thaw cycles. The initial WHC of fresh sample was $69.86 \%$. WHC was affected $(p<0.01)$ by thawing methods within cycles and among the cycles (Table 7-10). Moreover, WHC increased in cycle 1 and 2 but decreased greatly $(p<0.05)$ in cycle 3 . There were significant interactive effects found $(p<0.01)$ on WHC in different cycles and thawing methods. Thawing at $40^{\circ} \mathrm{C}$ in cycle 1 had the highest value of WHC and thawing at $4^{\circ} \mathrm{C}$ in cycle 3 had the lowest value of WHC among interactions (Table 11).

\section{Measurement of $\mathrm{pH}$}

The $\mathrm{pH}$ of the meat influences the rate of oxidation as well as the microbial shelf life and drip loss and vice versa. The initial $\mathrm{pH}$ of fresh beef sample was 6.15 , indicating the normal $\mathrm{pH}$ of beef within $2 \mathrm{~h}$ of slaughter. The $\mathrm{pH}$ was almost similar to control but slightly varied by thawing methods within and among the cycles (Table 7-10). Different thawing methods did not affect $(p>0.05) \mathrm{pH}$ value in cycle 1 and 3 . Thawing methods had little effect $(p<0.05)$ on $\mathrm{pH}$ value in cycle 2 . The final $\mathrm{pH}$ observed in this study was 5.27; thawing in tap water in cycle 3 (Table 9). Among the cycles significant $(p<0.01)$ change on $\mathrm{pH}$ value was observed (Table 10) but no interactive effects were found on $\mathrm{pH}$ value in different cycles-thawing methods. In this study, thawing at $4^{\circ} \mathrm{C}$ in cycle 1 had the highest and thawing in tap water in cycle 3 had the lowest value of $\mathrm{pH}$ among the interactions (Table 11).

\section{Measurement of Lipid oxidation}

\section{2-Thiobarbituric acid (TBARS) value}

There were a significant differences among the samples subjected to repeated freeze-thaw cycles in TBARS value. The initial TBARS value of fresh beef sample was 0.26 $\mathrm{MDA} / \mathrm{kg}$ beef and ranging within 0.26 to $0.51 \mathrm{MDA} / \mathrm{kg}$ beef. TBARS value was affected $(p<0.01)$ within cycles and among the cycles by different thawing methods (Fig. 4 and 5). Significant interactive effects $(p<0.01)$ were found on TBARS value in different cycles and thawing methods. Thawing at $40^{\circ} \mathrm{C}$ in cycle 3 had the highest and thawing at $4^{\circ} \mathrm{C}$ in cycle 1 had the lowest TBARS value 
Table 11. Freezing-Thawing interactive effects on physicochemical properties (mean \pm SE) of thawed beef samples in different cycles and thawing methods

\begin{tabular}{|c|c|c|c|c|c|c|}
\hline Interactions & $\begin{array}{c}\text { Thaw loss } \\
(\%)\end{array}$ & $\begin{array}{c}\begin{array}{c}\text { Drip loss } \\
(\%)\end{array} \\
\end{array}$ & $\begin{array}{c}\text { Cooking loss } \\
(\%)\end{array}$ & $\begin{array}{l}\text { WHC } \\
(\%)\end{array}$ & $\mathrm{pH}$ & $\begin{array}{c}\text { TBARS value } \\
\text { (mg MA/kg) }\end{array}$ \\
\hline $\mathrm{C}_{1} \times \mathrm{T}_{1}$ & $3.49 \pm 0.25$ & $14.05^{\mathrm{a}} \pm 0.17$ & $56.94^{\mathrm{a}} \pm 0.68$ & $77.83^{b} \pm 0.35$ & $6.04 \pm 0.04$ & $0.291^{\mathrm{f}} \pm 0.01$ \\
\hline $\mathrm{C}_{1} \times \mathrm{T}_{2}$ & $3.66 \pm 0.25$ & $7.04^{\mathrm{d}} \pm 0.17$ & $41.40^{e^{e}} \pm 0.68$ & $79.78^{\mathrm{a}} \pm 0.35$ & $5.92 \pm 0.04$ & $0.35^{\mathrm{d}} \pm 0.01$ \\
\hline $\mathrm{C}_{1} \times \mathrm{T}_{3}$ & $3.73 \pm 0.25$ & $6.05^{\mathrm{e}} \pm 0.17$ & $45.57^{\mathrm{d}} \pm 0.68$ & $73.81^{\mathrm{c}} \pm 0.35$ & $5.87 \pm 0.04$ & $0.29^{\mathrm{e}} \pm 0.01$ \\
\hline $\mathrm{C}_{2} \times \mathrm{T}_{1}$ & $6.13 \pm 0.25$ & $11.42^{\mathrm{b}} \pm 0.17$ & $49.59^{\mathrm{bc}} \pm 0.68$ & $74.73^{\mathrm{c}} \pm 0.35$ & $5.72 \pm 0.04$ & $0.32^{\mathrm{de}} \pm 0.01$ \\
\hline $\mathrm{C}_{2} \times \mathrm{T}_{2}$ & $6.54 \pm 0.25$ & $5.66^{\mathrm{ef}} \pm 0.17$ & $41.27^{\mathrm{e}^{\mathrm{e}}} \pm 0.68$ & $78.58^{\mathrm{ab}} \pm 0.35$ & $5.48 \pm 0.04$ & $0.50^{\mathrm{b}} \pm 0.01$ \\
\hline $\mathrm{C}_{2} \times \mathrm{T}_{3}$ & $6.57 \pm 0.25$ & $4.90^{\mathrm{fg}_{ \pm}} \pm 0.17$ & $47.92^{\mathrm{bcd}} \pm 0.68$ & $73.77^{c} \pm 0.35$ & $5.39 \pm 0.04$ & $0.46^{\mathrm{c}} \pm 0.01$ \\
\hline $\mathrm{C}_{3} \times \mathrm{T}_{1}$ & $12.51 \pm 0.25$ & $9.92^{\mathrm{c}} \pm 0.17$ & $47.13^{\mathrm{cd}} \pm 0.68$ & $54.67^{\mathrm{e}} \pm 0.35$ & $5.48 \pm 0.04$ & $0.35^{\mathrm{d}} \pm 0.01$ \\
\hline $\mathrm{C}_{3} \times \mathrm{T}_{2}$ & $12.76 \pm 0.25$ & $4.57^{\mathrm{g}} \pm 0.17$ & $46.24^{\mathrm{cd}} \pm 0.68$ & $56.46^{\mathrm{d}} \pm 0.35$ & $5.39 \pm 0.04$ & $0.57^{\mathrm{a}} \pm 0.01$ \\
\hline $\mathrm{C}_{3} \times \mathrm{T}_{3}$ & $12.81 \pm 0.25$ & $4.54^{\mathrm{g}} \pm 0.17$ & $51.15^{\mathrm{b}} \pm 0.68$ & $55.09^{\mathrm{de}} \pm 0.35$ & $5.27 \pm 0.04$ & $0.51^{\mathrm{b}} \pm 0.01$ \\
\hline $\begin{array}{c}\text { Level of } \\
\text { Significance }\end{array}$ & NS & $* *$ & $* *$ & $* *$ & NS & $* *$ \\
\hline
\end{tabular}

Means with different superscripts in each column are significantly different $(* * p<0.01)$. NS was not significantly different.

Note: $\mathrm{C}=$ Cycle $\left(\mathrm{C}_{1}=\right.$ Cycle $1 ; \mathrm{C}_{2}=$ Cycle $2 ; \mathrm{C}_{3}=$ Cycle 3$)$ and $\mathrm{T}=$ Treatment/Thawing methods $\left(\mathrm{T}_{1}=4^{\circ} \mathrm{C} ; \mathrm{T}_{2}=40^{\circ} \mathrm{C} ; \mathrm{T}_{3}=\right.$ Tap water $)$.

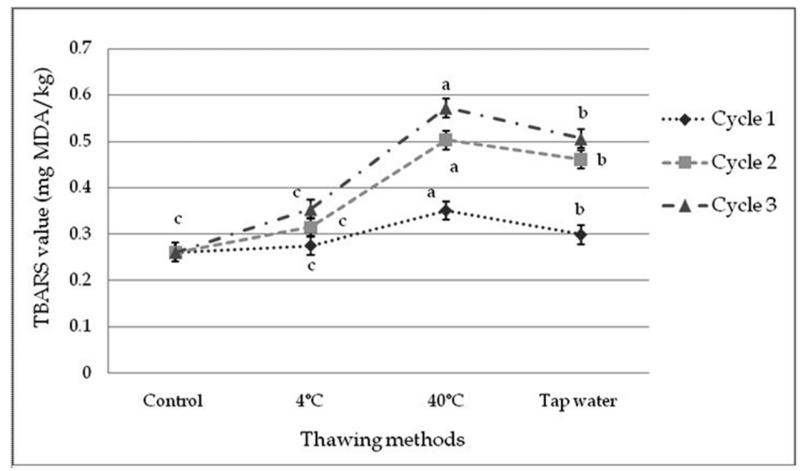

Fig. 4. Changes of TBARS value (mean \pm SE) in thawed beef samples compared to control in freeze-thaw cycle $-1,2 \& 3$.

among the interactions (Table 11).

\section{Microbiological analysis}

\section{Total viable count (TVC)}

The initial value of TVC for control was 5.12 Log CFU/ $\mathrm{g}$, indicating good quality beef. TVC was affected significantly $(p<0.01)$ by thawing methods within cycles and among the cycles (Fig. 6 and 8). TVC was decreased in cycle 1 but increased in cycle 2 and 3 subsequently in different thawing process which did not cross the initial count. TVC was significantly $(p<0.05)$ changed in different interactions of cycles and thawing methods. Thawing at $40^{\circ} \mathrm{C}$ in cycle 3 had the highest and thawing at $4^{\circ} \mathrm{C}$ in cycle 1 had the lowest TVC among the interactions (Table 12).

Total coliform count (TCC)

TCC was satisfactory in beef samples before and after

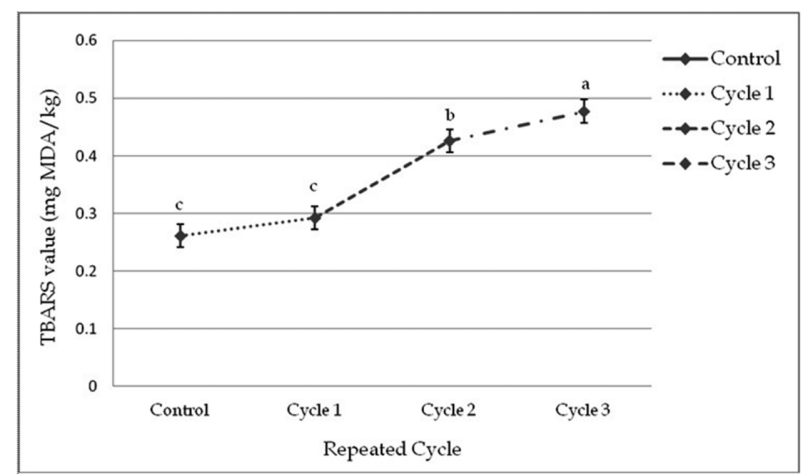

Fig. 5. Changes of TBARS value (mean \pm SE) in thawed beef samples compared to control in repeated cycles.

repeated freeze-thaw cycles. The initial TCC for control was $1.25 \mathrm{Log} C F U / g$. After freezing TCC was less than 1 Log CFU/g. Thawing methods did not affect $(p>0.05)$ the TCC within cycles and among the cycles. No interactive effects were observed on TCC in this study (Table 12).

\section{Total yeast-mould count}

Yeast-Mould count was also satisfactory level in this study. The initial yeast-mould count for control was 2.25 Log CFU/g. After freezing yeast-mould decreased gradually and in cycle 2 and three less than $1 \mathrm{Log} C F U / g$ was observed.

Thawing methods did not affect $(p>0.05)$ yeast-mould count within cycles but affected among the cycles $(p<$ 0.05 ) (Fig. 7 and 8). Significant interactive effects $(p<$ 0.05 ) on yeast-mould count were found. Thawing at $40^{\circ} \mathrm{C}$ in cycle 1 had the highest and thawing at $4^{\circ} \mathrm{C}$ in cycle 3 had the lowest yeast-mould count among the interactions (Table 12). 


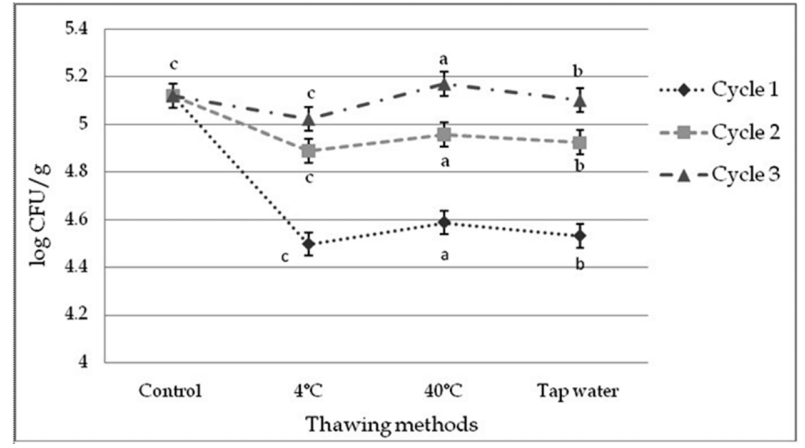

Fig. 6. Changes of total viable count (TVC) (mean \pm SE) in thawed beef samples compared to control in freezethaw cycle $-1,2 \& 3$.

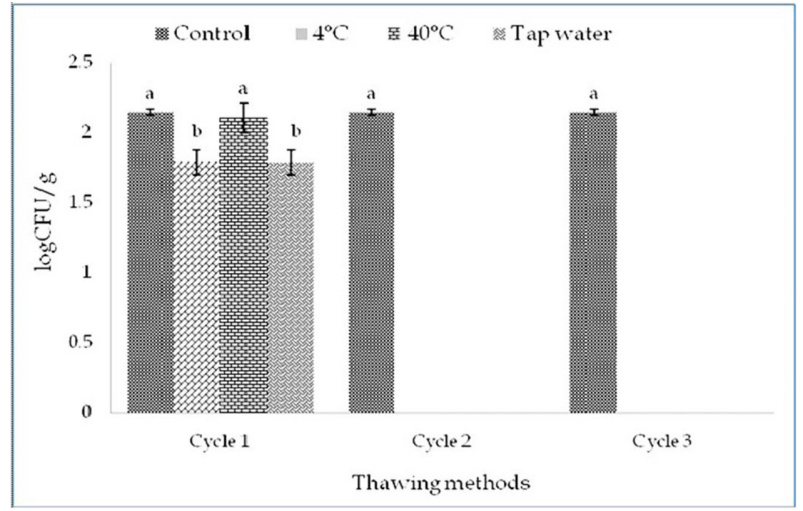

Fig. 7. Changes of total yeast-mould count (mean \pm SE) in thawed beef samples compared to control in freeze-thaw cycle $-1,2 \& 3$.

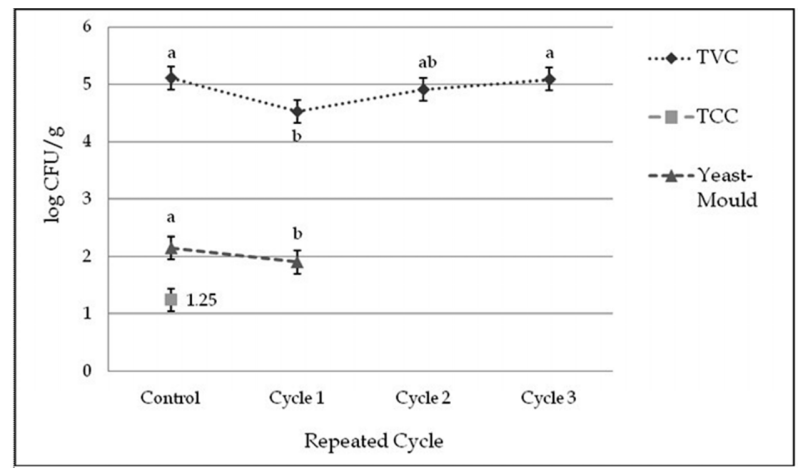

Fig. 8. Changes of total plate count (TVC), total coliform count (TCC) and yeast-mould count (mean \pm SE) in thawed beef samples compared to control in repeated cycles.

\section{Discussion}

\section{Sensory evaluation}

Beef and beef products are highly nutritious and perish-
Table 12. Freezing-Thawing interactive effects on total plate count, total coliform count and yeast-mould count $($ mean \pm SE) of thawed beef samples before cook in different cycles and thawing methods

\begin{tabular}{cccc}
\hline \hline Interactions & $\begin{array}{c}\text { TVC } \\
(\log \text { CFU/g) }\end{array}$ & $\begin{array}{c}\text { TCC } \\
(\log \text { CFU/g) }\end{array}$ & $\begin{array}{c}\text { Yeast-Mould } \\
(\log \text { CFU/g) }\end{array}$ \\
\hline $\mathrm{C}_{1} \times \mathrm{T}_{1}$ & $4.49^{\mathrm{g}} \pm 0.01$ & $<1 \pm 0.00$ & $1.79^{\mathrm{b}} \pm 0.51$ \\
$\mathrm{C}_{1} \times \mathrm{T}_{2}$ & $4.59^{\mathrm{f}} \pm 0.01$ & $<1 \pm 0.00$ & $2.12^{\mathrm{a}} \pm 0.51$ \\
$\mathrm{C}_{1} \times \mathrm{T}_{3}$ & $4.53^{\mathrm{fg}} \pm 0.01$ & $<1 \pm 0.00$ & $1.79^{\mathrm{b}} \pm 0.51$ \\
$\mathrm{C}_{2} \times \mathrm{T}_{1}$ & $4.89^{\mathrm{e}} \pm 0.01$ & $<1 \pm 0.00$ & $<1^{\mathrm{c}} \pm 0.51$ \\
$\mathrm{C}_{2} \times \mathrm{T}_{2}$ & $4.96^{\mathrm{d}} \pm 0.01$ & $<1 \pm 0.00$ & $<1^{\mathrm{c}} \pm 0.51$ \\
$\mathrm{C}_{2} \times \mathrm{T}_{3}$ & $4.92^{\mathrm{de}} \pm 0.01$ & $<1 \pm 0.00$ & $<1^{\mathrm{c}} \pm 0.51$ \\
$\mathrm{C}_{3} \times \mathrm{T}_{1}$ & $5.02^{\mathrm{c}} \pm 0.01$ & $<1 \pm 0.00$ & $<1^{\mathrm{c}} \pm 0.51$ \\
$\mathrm{C}_{3} \times \mathrm{T}_{2}$ & $5.17^{\mathrm{a}} \pm 0.01$ & $<1 \pm 0.00$ & $<1^{\mathrm{c}} \pm 0.51$ \\
$\mathrm{C}_{3} \times \mathrm{T}_{3}$ & $5.10^{\mathrm{b}} \pm 0.01$ & $<1 \pm 0.00$ & $<1^{\mathrm{c}} \pm 0.51$ \\
Level of & $*$ & $\mathrm{NS}$ & $*$ \\
Significance & & &
\end{tabular}

Means with different superscripts in each column are significantly different $\left({ }^{*} p<0.05\right)$. NS was not significantly different.

Note: $\mathrm{C}=$ Cycle $\left(\mathrm{C}_{1}=\right.$ Cycle $1 ; \mathrm{C}_{2}=$ Cycle $2 ; \mathrm{C}_{3}=$ Cycle 3$)$ and $\mathrm{T}=$ Treatment/Thawing methods $\left(\mathrm{T}_{1}=4^{\circ} \mathrm{C} ; \mathrm{T}_{2}=40^{\circ} \mathrm{C} ; \mathrm{T}_{3}=\right.$ Tap water $)$.

able food. Depending on the degree of processing following slaughter their spoilage time varies between 2 and $8 \mathrm{~d}$ under refrigeration (Marenzi, 1986). Spoilage is commonly detected by sensory and/or physicochemical or microbial analysis. After thawing frozen beef samples evaluated by a trained and untrained panel were found to have lower intensity of beef color, odor, juiciness, tenderness and overall acceptability compared to fresh beef samples. However, panel evaluations of the sensory attributes showed significant $(p<0.05)$ differences between fresh and thawed beef samples before cook and no significant $(p>0.05)$ differences between fresh and thawed beef samples after cook except cycle 2 (Fig. 1-3; Table 1-4) were found. The results of the present study were in agreement with Sen and Sharma (1999) reported that panelists found that the freeze thaw cycles did cause significant deterioration in color and odor of meat samples.

Sensory scores for appearance, flavor, tenderness, juiciness and overall acceptability of the beef samples remained similar till cycle two (Fig. 1-3 and Table 1-3). A gradual decline of these attributes might be due to the expected loss of moisture and volatile components from samples and condiments on storage of beef. Freezing procedures influence thawing loss, color and tenderness of beef (Farouk and Swan 1998; Honikel et al., 1986). Beef color is one of the key selection criteria for consumers making their purchase decisions and important indicator of the processing suitability of meat. Consumers use color as an indicator of meat freshness or even eating quality (Mancini and Hunt, 2005; Ngapo et al., 2004). Whipple 
and Koohmaraie (1992) stated that freezing temperature and rate as well as thaw rate may affect the extent to which aging meat after freezing improves tenderness, because of possible detrimental or beneficial effects of freezing itself. The results of the present study were in agreement with previous reports. Freezing and thawing rates have significant effects on Warner Bratzler shear force or sensory tenderness. The result of the present study supported by Paul and Child's (1937) research on freezing and thawing roasts, in that total moisture, drip loss and tenderness of cooked beef were affected by repeated freeze-thaw cycles. Lee et al. (1950) also found significant effects on palatability due to freezing and thawing; freezing and thawing cycle has an impact on the meat quality. When meat is frozen, ice crystals form inside the cells of muscle tissue and puncture the cell walls. That's why meats leak juices when they are thawed. If meats refrozen accelerating further moisture loss, and, when this meats eventually cook, any one may find it dense and dry in texture. The result of this experiment is also related to Lui et al. (2010) findings. Lui et al. (2010) observed that trained sensory panel rated the freeze/thawed meat significantly less tender than the chilled meat.

\section{Physicochemical properties}

\section{Measurement of moisture loss}

The moisture content of beef trimmings were established as $74.01 \%$ by standard methods (Kenny et al., 2008) which is in agreement with present study (74.05\%). Freezing and thawing alter both the content and the distribution of moisture in beef tissue. Moisture as a quality characteristic in meat can be evaluated in several ways, including thaw loss, drip loss, cooking loss, water holding capacity and total moisture contents. Changes in thaw loss, drip loss, cooking loss and water holding capacity (WHC) during repeated freeze-thaw cycles and interactive effects of treatments and cycles are presented in Table 7-11.

The amount of thaw loss may be a measure of damage to muscular tissue structure in the freezing process, reflecting the effectiveness of different thawing methods (Kondratowicz et al., 2008). Thawing methods had no significant effect on beef weight loss. Thaw loss was increased with repeated freeze-thaw cycles. This finding agrees with Muela et al. (2010) and Soyer et al. (2010) reported that an increase in freeze-thaw cycles or a reduction in the rate of freezing (characteristic freezing time increases) results in increased thaw loss. The range of thaw loss was $3.49-12.81 \%$. According to Xia et al. (2009), thawing loss is conditioned by the number of freezingthawing cycles, i.e. thawing loss increases in direct ration with the number of freezing-thawing cycles, starting from $3.5 \%$ of loss in the first cycle to $18.27 \%$ in the fifth cycle. $1-10 \%$ thaw loss was observed in pork carcass (Melody et al., 2004).

In case of drip loss all treatments showed a significant change over the course of the trial. Thawing at $4^{\circ} \mathrm{C}$ showed the higher drip loss in every cycle which agreed to Ambrosiadis et al. (1994) reported that rapid thawing of meat by submergence in water decreased the drip loss and in case of refrigerated thawing ( $28 \mathrm{~h}$ ), which resulted in the highest drip loss. In this study, drip loss was within $14.05 \%$ to $4.54 \%$. In general, drip loss was decreased with the number of repeated freeze-thaw cycles. Drip loss is exacerbated by cutting, heating, grinding, pressing, and particularly freeze-thawing. Up to $18.27 \%$ drip loss is observed by freeze-thawing pork (Xia et al., 2009). Exudates (drip or thaw loss) are closely related to muscle protein oxidation and denaturation which are responsible for muscle $\mathrm{pH}$ decline, discoloration, and toughness (Traore et al., 2012). Moreover, changes of drip or thaw loss are also interlinked with the rate of $\mathrm{pH}$ and the temperature decline post mortem, the rate of post mortem glycolysis, the degree of actomyosin cross-linking during rigir mortis, residual ATP levels final $\mathrm{pH}$ and the activity of a multitude of enzymes (Lawrie, 1998). On the other hand, the loss of exudates (drip or thaw loss) from beef is unavoidable, because some loss of moisture occurs due to the presence of water in a free form in muscle tissue (Joo and Kim, 2011) during freeze-thaw. Amount of exudates can be reduced to a minimum by controlling WHC (Jeong et al., 2011).

Both drip loss and cooking loss were affected by freezethawing $(p<0.01)$ cycles. Loss of moisture due to cooking has been reported no difference between fresh and frozen meat samples, as well as for samples frozen and thawed at different rates (Leygonie et al., 2012) which are similar to this study. The cooking loss was not affected by the freeze-thaw cycles, because the water expelled during cooking originates mostly from chemically bound water ( $10 \%$ of the total fluid) and from the fat that melts, which was not affected by freezing and thawing (Vieira et al., 2009). Moreover, cooking loss in pre-rigor muscle decreased due to exposure of hydrophilic groups of myofibrillar protein, resulting in greater hydrogen bonding of water (Macfarlane, 1973).

Another important functional property of beef is WHC, in particular water absorption and retention by the protein 
structures of muscular tissue as well as water retention during heat processing (HuffLonergan and Lonergan 2005). In general freezing, frozen storage and thawing all contribute to a decrease in the water-holding capacity of meat (Vieira et al., 2009). In cycle one and two WHC was higher than the control but in cycle $3 \mathrm{WHC}$ was decreased than the control. An initial increase and a subsequent decrease in WHC have been reported (Joo et al., 1999; Kristensen and Purslow 2001; Straadt et al., 2007). WHC was also affected by thawing methods and the combined effect of thawing methods and freeze-thawing cycles. According to Deatherage and Hamm (1960) slow freezing $\left(\right.$ at $-15^{\circ} \mathrm{C}$ ) of beef (both ground and cuts) resulted in a small but significant decrease in WHC. Except cycle 3 the result of WHC in this study was satisfactory which agreed to Nasreen et al. (2012). Inappropriate freezing and thawing may significantly deteriorate the ultimate quality of meat. Meat used for industrial purposes most often thawed naturally in the atmospheric air or under uncontrolled conditions. This process may lead to considerable moisture losses and alter the physicochemical properties of beef (Kondratowicz et al., 2005).

\section{Measurement of $\mathrm{pH}$}

The $\mathrm{pH}$ of the samples remained almost similar up to $75 \mathrm{~d}$ of frozen storage $\left(-20 \pm 1^{\circ} \mathrm{C}\right)$. This might be due to inhibition of microbial growth at frozen storage. A significantly low $\mathrm{pH}$ value was observed during thawing in tap water in freeze-thaw cycle 3 (pH 5.27). The decrease in $\mathrm{pH}$ due to freezing and thawing most likely arose from the loss of minerals and small protein compounds as exudates, thereby changing the ionic balance in the beef which resulted in a decreased pH (Vieira et al., 2009). This might also be explained by the increase in glycolysis with subsequent thawing and phosphorylase activation associated with changes of $\mathrm{pH}$ and free $\mathrm{Ca}^{2+}$ (Elkhalifa et al., 1984). This result was also in agreement with Jun et al. (2012) stated that $\mathrm{pH}$ decreased $(p<0.05)$ within the first 10 freeze-thaw cycles but increased $(p>0.05)$ after 5 further cycles. Further researches are required to examine the influence of repeated freeze-thaw cycles on beef $\mathrm{pH}$ concerned with different methods and rate of thawing.

\section{Measurement of lipid oxidation}

Fresh meat undergoes major undesirable changes during storage at both refrigeration and freezing temperatures. Lipid peroxidation is one of the primary mechanisms of quality deterioration in stored foods, especially in muscle tissues. Lipid oxidation is a major factor that determines the sensory, functional, and nutritional quality of beef and beef products. TBARS is a secondary oxidation product commonly used as a measurement of lipid oxidation. The secondary by-products of lipid oxidation such as aldehydes have generated cytotoxic and genotoxic properties due to their high reactivity. TBA and peroxide values increased significantly during storage time and they correlated positively with each other. Lipid oxidation is an important quality parameter for meat and meat products, because it may lead to rancidity (Jin et al., 2009; Nolsøe and Undeland, 2009). When beef and beef products are stored under frozen conditions, microbial spoilage may be delayed but fat deterioration occurs and the beef constituents may be oxidized. A general trend of increase in TBARS during refrigerated and frozen storage of meat and meat products has been reported by many workers (Devatkal et al., 2004; Rajkumar et al., 2004). TBARS value increased slowly within the cycles and among the cycles by thawing methods in present study. According to Tan \& Shelef (2002), fat oxidation in frozen meats proceeds at a slower rate than in refrigerated meat and the TBARS values showed only small differences during frozen storage at $-20^{\circ} \mathrm{C}$ for $69 \mathrm{~d}$. The results of the present study were in agreement with previous report (Tan \& Shelef, 2002). In this experiment TBARS value is ranging within 0.26 to 0.51 . So the TBARS values of present study remained lower than the acceptable level for rancidity $(1.0 \mathrm{mg} / \mathrm{kg})$. The oxidative stability of meat depends upon the balance of anti and pro-oxidants, and the composition of oxidation substrates including polyunsaturated fatty acids (PUFA), cholesterol, proteins, and pigments (Bertelsen et al., 2000). Beef is a rich source of these compounds.

Thawing at $40^{\circ} \mathrm{C}$ showed the highest TBARS value in every cycle in this experiment, because of heating could affect many factors involved in lipid oxidation. Heat disrupts the muscle cell structure, and inactivates antioxidative enzymes and releases oxygen from oxymyoglobin. High temperature decreases the activation energy for oxidation and breaks down hydroperoxides to free radicals, which propagate lipid peroxidation. Heating seemed to be very pro-oxidative for the pre-frozen meat samples as measured by the high TBARS values. This statement supports the results of present study. Jin-ping et al. (2012) reported that as the number of freeze-thaw cycles increased and TBARS value increased significantly $(p<0.05)$. As a result freeze-thaw cycles affected the physicochemical quality and lipid degradation of beef muscle, causing the deterioration of beef quality. The result of the present study was 
in agreement with previous statement (Jin-ping et al., 2012).

\section{Microbiological assessment}

All microbial counts of beef samples determined during frozen storage were low in number and can be categorized as satisfactory and within the acceptable values. The initial value of TVC for control in beef was 5.12 Log CFU/ $\mathrm{g}$, indicating good quality of beef that agreed with that of standardization and quality control by Dempster (1986), who concluded that the total counts must be within the range $10^{3}-10^{7} \mathrm{CFU} / \mathrm{g}$ of meat. No significant increase in growth of organisms occurred during $11 \mathrm{wk}$ of frozen storage when compared to microbial growth at $0 \mathrm{~d}$ of storage for all treatments (Fig. 6-9). This could be due to lower $\mathrm{pH}$ and no available nutrients favorable for microbial growth. There was no significant change in total coliform counts and total yeast-mould count; thereafter TVC increased significantly $(p<0.01)$ due to handling contamination during thawing process. Due to the bad storage condition and thawing that leads to prepare a suitable condition for microbial growth, or during handling and storage the microbes reached to the consumers beef products (Berry, 1998). However, TVC of beef did not exceed the permissible level of microbial standards $\left(\log 10^{6} \mathrm{CFU} / \mathrm{g}\right.$ of sample) in meat as reported by Jay (1996). Moreover, at commercial freezing temperatures $\left(-18\right.$ to $\left.-24^{\circ} \mathrm{C}\right)$, all microbial activity was suspended (Tucker, 2011). Total coliform was initially $1.25 \mathrm{Log} \mathrm{CFU} / \mathrm{g}$ but after frozen TCC decreased. The occurrence of coliform counts during storage was very rare, indicating better sanitary measures adopted during processing which was in agreement with Das et al. (2008).

Thawing in a refrigerator was recommended (Fennema, 1966) to suppress the growth of microorganisms which may occur if the food material is allowed to remain at temperatures near or above $0^{\circ} \mathrm{C}$ for extended periods. Another similar study (Marriott et al., 1980) indicated that ground beef should be thawed at refrigerator temperatures for $24 \mathrm{~h}$ to avoid undesirable bacterial growth. In general, thawing at temperatures ranging from room temperature to $49^{\circ} \mathrm{C}$ is considered to be detrimental in inducing surface spoilage prior to the completion of thawing (Fennema, 1964) which is in agreement with the present findings.

\section{Conclusion}

From the results of the present study, it may be con- cluded that, as the number of repeated freeze-thaw cycles increased it affected the sensory, physicochemical quality and microbiological quality of beef muscle, causing the deterioration of beef quality, but improving the microbiological quality. Repeated freeze and thaw should be minimized in terms of beef color for commercial value and water holding capacity and tenderness/juiciness for eating quality. From the results of the present study it may also be concluded that refrigerator thawing $\left(4^{\circ} \mathrm{C}\right)$ is more suitable than running tap water or warm water $\left(40^{\circ} \mathrm{C}\right)$ thawing, and avoiding repeated freezing and thawing of beef was the best.

\section{References}

1. Ahn, D. U., Olson, D. C., Jo, C., Chen, X., Wu, C. and Lee, J. I. (1998) Effect of muscle type, packaging and irradiation on lipid oxidation, volatile production, and color in raw pork patties. Meat Sci. 49, 29-39.

2. Ambrosiadis, I., Theodorakakos, N., Georgakis, S., and Lekas, S. (1994) Influence of thawing methods on the quality of frozen meat and drip loss. Fleishwirtsch. 74, 284-286.

3. AMSA (1995) Research guidelines for cookery, sensory evaluation, and instrumental tenderness measurements of fresh meat. Chicago III. American Meat Science Association and Nutritional Live Stock and Meat Board.

4. Berry, E. D. and Koohmaraic, M. (2001) Effect of different levels of beef bacterial microflora on the growth and survival of Escherichia coli 0157:H7 on beef carcass tissue. J. Food Prod. 64, 1138-1144.

5. Bertelsen, G., Jakobsen, M., Juncher, D., Moller, J., KrogerOhlsen, M., Weber, C., and Skibsted, L. H. (2000) Oxidation, shelf-life and stability of meat and meat products. In Proceedings of the 46th international congress of meat science and technology (4.II-L2:516-524).

6. Bing, L. and Sun, D. W. (2002) Novel methods for rapid freezing and thawing of foods-a review. J. Food Eng. 54, 175182.

7. Buege, J. A. and Aust, S. D. (1978) Microsomal lipid peroxidation. Methods Enzymol 52, 302-310. Academic press Inc.

8. Chemat, F. and Zill-e-Huma, K. M. K. (2011) Application of ultrasound in food technology: processing, preservation and extraction. Ultrasonics Sonochemistry. 18, 813-835.

9. Das, A. K., Anjaneyulu, A. S. R., Verma, A. K., and Kondaiah, N. (2008) Effect of full-fat soy paste and soy granules on quality of goat meat patties. Int. J. Food Sci. Technol. 43, 383-392.

10. Deatherage, F. E. and Hamm, R. (1960) Influence of freezing and thawing on hydration and charges of the muscle proteins. Food Res. 25, 623-629.

11. Dempster, J. F. (1986) Bacteriological status of minced beef. Irish J. Food Sci. Technol. 2, 1-11.

12. Devatkal, S., Mendiratta, S. K., and Kondaiah, N. (2004) Quality characteristics of loaves from buffalo meat, liver and ve- 
getables. Meat Sci. 67, 377-383.

13. Eastridge, J. S. and Bowker, B. C. (2011) Effect of rapid thawing on the meat quality attributes of USDA select beef strip loins steaks. J. Food Sci. 76, 156-162.

14. Elkhalifa, E. A., Anglemier, A. F., Kennick, W. H., and Elgasim, E. A. (1984) Influence of pre-rigor pressurization on postmortem beef muscle creatine phosphokinase activity and degradation of creatine phosphate and adenosine triphosphate. J. Food Sci. 49, 595-597.

15. Farouk, M. M. and Swan, J. E. (1998) Effect of rigor temperature and frozen storage on functional properties of hotboned manufacturing beef. Meat Sci. 49, 233-247.

16. Farouk, M. M., Wieliczko, K. J., and Merts, I. (2004) Ultrafast freezing and low storage temperatures are not necessary to maintain the functional properties of manufacturing beef. Meat Sci. 66, 171-179.

17. Fennema, O. and Powrie, W. D. (1964) Fundamentals of lowtemperature food preservation. Adv. Food Res. 13, 219-347.

18. Fennema, O. (1966) An over-all view of low temperature food preservation. Cryobiol. 3, 197-213.

19. Grau, R. and Hamm, G. (1953) Eine Einfache Methode zur Bestimmung der Wasserbindung in Muskel. Die Naturwissenschaften 40, 277-259.

20. Honikel, K. O., Kim, C. J., Hamm, R., and Roncales, P. (1986) Sarcomere shortening of pre rigor muscles and its influence on drip loss. Meat Sci. 16, 267-282.

21. Huff-Lonergan, E. and Lonergan, S. M. (2005) Mechanism of water-holding capacity of meat: The role of postmortem biochemical and structural changes. Meat Sci. 71, 194-204.

22. ISO (1995) Recommendation of the meeting of the subcommittee, International Organization for Standardization, on meat and meat products. ISO/TC-36/SC-6. The Netherlands. 1018.

23. Jay, J. M. (1996) In Modern food microbiology ( $4^{\text {th }}$ Ed.). New Delhi: CBS Publishers and Distributors.

24. Jeong, J. Y., Kim, G. D., Yan, H. S., and Joo, S. T. (2011) Effect of freeze-thaw cycles on physicochemical properties and color stability of beef semimembranosus muscle. Food Res. Int. 44, 3222-3228.

25. Jin, S. K., Kim, I. S., Choi, Y. J., Kim, B. G., and Hur, S. J. (2009) The development of imitation crab sticks containing chicken breast surimi. LWT Food Sci. Technol. 42, 150-156.

26. Jin-ping, L. I., Xing-lian, X. U., and Guang-hong, Z. H. O. U. (2012) Effect of freeze-thaw cycle on meat quality of beef striploin. Jiangsu J. Agril. Sci. 95, 230-237 (Key Laboratory of Meat Processing and Quality Control, Ministry of Education, National Center for Meat Quality and Safety Control, Nanjing Agricultural University, Nanjing 210095, China).

27. Joo, S. T., Kauffman, R. G., Kim, B. C., and Park, G. B. (1999) The relationship of sarcoplasmic and myofibrillar protein solubility to color and water-holding capacity in porcine longissimus muscle. Meat Sci. 52, 291-297.

28. Joo, S. T. and Kim, G. D. (2011) Meat quality traits and control technologies. In Joo ST (Ed.), Control of meat quality. pp. 6-10.

29. Jun, Q., Chunbao, L., Yinji, C., Feifei, G., Xinglian, X., and
Guanghong, Z. (2012) Changes in meat quality of ovine longissimusdorsi muscle in response to repeated freeze and thaw. Meat Sci. 92, 619-626.

30. Kenny, T., Ward, P., Lennon, A., Sullivan, P., McDonald, K., and O'Neill, E. (2008) Adding value of forequarter musclesA manual for industry. Teagasc ISBN-101-84170-5160.

31. Kondratowicz, J. and Chwastowska, I. (2005) Właściwości technologic znemięsa wiper zowegow zalezności odczasuzamrazal niczego przechowy waniaimetody rozmrazania. Zywność (Nauka, Technologia, Jakość). 3, 11-20.

32. Kondratowicz, J., Chwastowska-Siwiecka, I. and Burczyk, E. (2008) Technological properties of pork thawed in the atmospheric air or in the microwave oven as determined during a six-month deep-freeze storage. Animal Sci. Papers Reports 26, 175-181.

33. Kristensen, L. and Purslow, P. P. (2001) The effect of ageing on the water-holding capacity of pork: Role of cytoskeletal proteins. Meat Sci. 58, 17-23.

34. Lawrie, R. A. (1998) Lawrie's meat science (6 $6^{\text {th }}$ ed.). Lancaster, PA: Technomic Publishing Inc.

35. Lee, Frank, A., Robert, F. B., Pearson, A. M., John, I. M., and Frances, V. (1950) Effect of freezing rate on meat appearance, palatability, and vitamin content of beef. J. Food Sci. 15, 8-15.

36. Leygonie, C., Britz, T. J. and Hoffman, L. C. (2012) Meat quality comparison between fresh and frozen/thawed ostrich $M$. iliofibularis. Meat Sci., provisionally accepted.

37. Lui, Z., Xiong, Y., and Chen, J. (2010) Protein oxidation enhances hydration but suppresses water-holding capacity in Porcine Longissimus muscle. J. Agric. Food Chem. 58, 1069710704.

38. Macfarlane, J. J. (1973) Pre-rigor pressurization of muscle: effects on $\mathrm{pH}$, shear value and taste panel assessment. J. Food Sci. 38, 294-297.

39. Mancini, R. A. and Hunt, M. C. (2005) Current research in meat color. Meat Sci. 71, 100-121.

40. Marenzi, C. (1986) Proper meat storage prevents spoilage. Poultry-Misset. 6, 12-15.

41. Marriott, N. G., Garcia, R. A., Pullen, J. H., and Lee, D. R. (1980) Effect of thaw conditions on ground beef. J. Food Protection 43, 180-184.

42. McMillin, K. W. (2008) Where is MAP Going? A review and future potential of modified atmosphere packaging for meat. Meat Sci. 80, 43-65.

43. Melody, J. L., Lonergan, S. M., Rowe, L. J., Huiatt, T. W., Mayes, M. S., and Huff-Lonergan, E. (2004) Early postmortem biochemical factors influence tenderness and water holding capacity of three porcine muscles. J. Anim. Sci. 82, 1195-1205.

44. Muela, E., Sañudo, C., Campo, M. M., Medel, I., and Beltrán, J. A. (2010) Effect of freezing method and frozen storage duration on instrumental quality of lamb throughout display. Meat Sci. 84, 662-669.

45. Nasreen, M. A., Ayad, B. A., and Hozan, J. H. (2012) Study of some chemical, quality, sensory and bacteriology characteristics of frozen beef meat imported to Sulaimani as com- 
pared to local meat. J. Tikrit University for Agril. Sci. 12, 2939.

46. Ngapo, T. M., Martin, J. F., and Dransfield, E. (2004) Consumer choices of pork chops: Results from three panels in France. Food Quality and Preference 15, 349-359.

47. Nolsøe, H. and Undeland, I. (2009) The acid and alkaline solubilization process for the isolation of muscle proteins: state of the art. Food Bioprocess Technol. 2, 1-27.

48. Paul, P. and Child, A. (1937) Effect of Freezing and Thawing Beef Muscle upon Press Fluid, Losses, and Tenderness. $J$. Food Sci. 2, 339-347.

49. Rahman, S. M., Park, J., Song, K. B., Al-Harbi, N. A., and Oh, D. H. (2012) Effect of slightly acidic low concentration electrolyzed water on microbiological, physicochemical, and sensory quality of fresh chicken breast meat. J. Food Sci. 77, M35-41.

50. Rajkumar, V., Agnihotri, M. K., and Sharma, N. (2004) Quality and shelf life of vacuumed and aerobic packed chevon patties under refrigeration. Asian-Austral. J. Anim. Sci. 17, 548-553.

51. Sen, A. and Sharma, N. (1999) Effect of freeze-thaw cycles during storage on quality of meat and liver of buffalo. J. Food Sci. Technol. 36, 28-31.

52. Soyer, A., Özalp, B., Dalmış, Ü. and Bilgin, V. (2010) Effects of freezing temperature and duration of frozen storage on lipid and protein oxidation in chicken meat. Food Chem. 120, 1025-1030.

53. Straadt, I. K., Rasmussen, M., Andersen, M. J., and Bertram, H. C. (2007) Aging-induced changes in microstructure and water distribution in fresh and cooked pork in relation to water-holding capacity and cooking loss - A combined confocal laser scanning microscopy (CLSM) and low-field nuclear magnetic resonance relaxation study. Meat Sci. 75, 687695.
54. Sultana, A., Huque, K. S., and Amanullah, S. M. (2009) Development of tasty marinating kit for tenderization and preservation of beef chuck. The Bangladesh Veterinarian 26, 2330.

55. Sultana, A., Nakanishi, A., Roy, B. C., Mizunoya, W., Tatsumi, R., Ito, T., Tabata, S., Rashid, H., Katayama, S., and Ikeuchi, Y. (2008) Quality Improvement of Frozen and Chilled Beef biceps femoris with the Application of Salt-bicarbonate Solution. Asian-Austral. J. Anim. Sci. 21, 903-911.

56. Tan, W. and Shelef, L. A. (2002) Effect of sodium chloride and lactates on chemical and microbial changes in refrigerated and frozen fresh ground pork. Meat Sci. 62, 27-32.

57. Traore, S., Aubry, L., Gatellier, P., Przybylski, W., Jaworska, D., Kajak-Siemaszko, K., and Santé-Lhoutellier, V. (2012) Higher drip loss is associated with protein oxidation. Meat Sci. 90, 917-924.

58. Tucker, G. S. (2011) Food biodeterioration and methods of preservation. In: Coles R, Kirwan MJ, editors. Food and beverage packaging technology. $2^{\text {nd }} \mathrm{Ed}$. West Sussex: Blackwell Publishing Ltd 31-58.

59. Vieira, C., Diaz, M. Y., Martínez, B., and García-Cachán, M. D. (2009) Effect of frozen storage conditions (temperature and length of storage) on microbial and sensory quality of rustic crossbred beef at different stages of aging. Meat Sci. 83, 398404.

60. Whipple, G. and Koohmaraie, M. (1992) Freezing and calcium chloride marination on beef tenderness and calpastatin activity. J. Anim. Sci. 70, 3081-3085.

61. Xia, X., Kong, B., Liu, Q., and Liu, J. (2009) Physicochemical change and protein oxidation in porcine longissimusdorsi as influenced by different freeze-thaw cycles. Meat Sci. 83, 239-245.

(Received 2014.3.26/Revised 2014.6.30/Accepted 2014.7.14) 